\title{
Employees' Covenants Not to Solicit Former Patrons
}

That absolute freedom of contract should not exist in the legal sense and does not exist in either the legal or the factual sense is but a truism. ${ }^{1}$ But it is also true that many courts, in the language of their opinions at least, have continued to follow the doctrine expressed by Sir George Jessel some three score years ago:

". . . if there is one thing which more than another public policy requires, it is that men of full age and competent understanding shall lave the utmost liberty of contracting, and that their contracts when entered into freely and voluntarily slall be held sacred and shall be enforced by courts of justice."2

The era of face-to-face bargaining between individuals acting independently and for themselves is in the past. ${ }^{3}$ Economically one party (often but not necessarily by reason of corporate size and strength) may be so far dominant as to renove almost entirely the free consent of the servient party. Contracts so entered into have been called con-

1 Cardoza, The Paradoxes of Legat Science (1928) 116, 124 ; Pound, InterpRETATIONS OF LEGAL HistoRY (1923) $61 \mathrm{ff}, 123,147,163$; Adler, Labor, Capital, and Business at Common Law (1916) 29 HaRv. L. Rev. 241; Allen, Status and Capacity (1930) 46 L. Q. REv. 277, 287; Frankfurter, Hours of Labor and Realism in Constitutional Law (1916) 29 HaRv. L. REv. 353; Patterson, The Delivery of a Life Insurance Policy (1919) 33 ibid. 198, 222; Pound, Administration of Justice in the Modern City (1913) 26 ibid. 302, 310; Pound, The End of Law as Developed in Legal Rules and Doctrines (1914) 27 ibid. 195, 228; Pound, The End of Law as Developed in Juristic Thought (1917) 30 ibid. 201, 203; Williston, Freedom of Contract (1921) 6 CoRN. L. Q. 365, Selected REAdings on Contracts (1930) 100.

2 Printing \& Numerical Registration Co. v. Sampson (1875) L. R. 19 Eq. 462, 44 L. J. R. (N.s.) 705. But Byles, J., in Mumford v. Gething (1859) 7 C. B. (N.s.) 305,325 , said, "It is a popular, but in iny judgment a mistaken, notion that parties ought to be at liberty to enter into contracts after their own fashion." Cf. the famous remark of Holmes, J., dissenting in Lochner v. New York (1905) 198 U. S. 45, 75, 25 Sup. Ct. 539, 546: "The Fourteenth Amendment does not enact Mr. Herbert Spencer's Social Statics." See quotations from opinions collected in Note (1931) 31 CoL. L. Rev. 687.

3 Llewellyn, What Price Contract? (1931) 40 YALE L. J. 704, 728; Pound, Administration of Justice in the Modern City, supra note 1; Wright, Opposition of the Law to Business Usages (1926) 26 Cor. L. Rev. 917, 931.

Frankfurter, $o p$. cit. supra note 1, at 363: "The underlying assumption was, of course, that industry presented only contract relations between individuals. That industry is part of society, the relation of business to the community, was naturally enough lost sight of in the days of pioneer development and free land."

Adler, op. cit. supra note 1, at 272: "So long as any problem of labor or capital or business is treated in law merely as a problem between individuals, the common law cannot be enforced and the real evils which produce these problems cannot be remedied except by legislation." 
tracts of adhesion; that is, the servient party has no choice as to terms but must adhere to the proposition offered him. ${ }^{4}$ These contracts of adhesion are generally earmarked by standardized forms and inadequacy of consideration. ${ }^{5}$ The courts (and legislatures) have recognized the inequality between the parties to such contracts in a number of situations: lender and borrower; ${ }^{6}$ insurer and insured $;^{7}$ banker and depositor $;^{8}$ manufacturer and distributor or retailer; ${ }^{8}$ and, (though to a lesser extent, perhaps, by judicial decision) employer and employee. ${ }^{10}$

A recent Louisiana case ${ }^{11}$ raises again the question of judicial recognition of inequality of bargaining power between employer and employee. The plaintiff corporation absorbed nearly all the laundries and dry-cleaning establishments in the city of Shreveport. The defendants, who had been employed by two of the former companies for two

4 Patterson, op. cit. supra note 1, at 222: "This expressive term seems worthy of a place in our legal vocabulary," citing authorities on usage of the term in civil law and international law. See Notes (1927) 27 Cor. L. Rev. 73, 80; (1927) 27 ibid. 430 .

5 Authorities cited in note 4, supra; Llewellyn, op. cit. supra note 3, at 731 .

6 Usury statutes, rules concerning the mortgagor's equity of redemption. See Pound, INTERpretations of Legax History (1923) 123; Llewellyn, op. cit. supra note 3, at 728, 732, 744; Pound, The End of Law as Developed in Legal Rules and Doctrines, supra note 1 , at 228.

7 Patterson, op. cit. supra note 1, at 222; Pound, The End of Law as Developed in Legal Rules and Doctrines, supra note 1, at 229; Notes (1927) 27 Cor. L. REv. 430; (1932) 32 ibid. 522.

8 Notes (1927) 27 Cor. L. REv. 73; (1927) 27 ibid. 430.

9 Notes (1927) 27 Cor. L. Rev. 430; (1931) 31 ibid. 830.

10 Labor legislation is beyond the scope of this article, but see: Adler, op. cit. supra note 1; Frankfurter, op. cit. supra note 1; Pound, The End of Law as Developed in Legal Rules and Doctrines, supra note 1, at 228; Williston, Freedom of Contract, supra note 1; Note (1931) 31 Coz. L. Rev. 687.

Llewellyn, op. cit. supra note 3, at 744: "The lop-sidedness of bargam-result is thus taken as the inark of lop-sidedness of bargaim-making. But the motivation being apparently not wholly conscious, the result has been (as so often during caselaw growth) confusion in doctrine and uncertainty of outcome; and-natural enough in a business economy-a relief of smaller business men which finds little counterpart in the case of the laborer."

For cases of releases of injury claims granted by railroad employees for imadequate consideration, see Note (1927) 27 CoL. L. REv. 430.

Apparently the American cases go so far in the employer's favor as to allow him by contract to exercise a power of fixing the compensation to be paid for services rendered. See Note (1916) 4 CALIF. L. REv. 498.

Many writers have seen the need for further recognition of the ordinary employee's inequality; Pound, The End of Law in the Development of Legal Rules and Doctrines, supra note 1, at 229: "Equity insisted on unoral conduct on the part of creditors; we now insist on social conduct on the part of employers. We insist upon protecting men against themselves so as to secure the social interest in the full moral and social life of every individual."

See also authorities cited in notes 1,3 , supra.

11 Shreveport Laundries, Inc. v. Teagle (La. Ct. of App. Feb., 1932) 139 So. 563. 
or three years as solicitors and collectors, remained in plaintiff's employ for some six months. Then each defendant, on pain of dismissal, was required to sign a standardized contract providing among other things that he would not solicit any of the plaintiff's customers nor in any way attempt to take away any of the plaintiff's customers for the period of six months after termination of the employment. The tern of employment was one year, and from year to year, but either party might terminate the agreement by two weeks' notice. The defendants received the same compensation under the new contract as under the old. After a few months one defendant was discharged upon his refusal to accept a decrease in wages. The other defendant left when the "plaintiff sought to impose conditions on his services more onerous than those of the written contract, ..."12 Both defendants entered the service of a competitor and sought business from old customers along their previous routes. One trial judge ordered enforcement of the restrictive covenant; the other held the contract null for lack of a "serious consideration." The appeals were consolidated.

On appeal, the court of appeal held the contract unenforceable for lack of a serious consideration. The court set the new salary off against the old, and concluded that no serious consideration was received for the additional promise contained in the covenant not to compete. That the true basis of the decision is a recognition of the inequahty in bargaining power between the parties and that the decision itself is an attempt to equalize that factor seems indisputable. The court says:

"Therefore it appears clear to us that the compensation coming to defendants under the new contract, being the same as in the old one, was not the controlling cause, nor the primary consideration, that induced them to sign it. Under the stress of existing conditions, and with the knowledge of certain discharge if they refused to sign the proffered contract, they affixed their signatures to it, giving the plaintiff the right to terminate it on two weeks' notice, and bound themselves, respectively, not to engage in the pursuit of the avocation by which they earned a living, on the route embraced in their employment (a very large part of the city of Shreveport) for the period of six months. . . .

"Another unequal effect of this contract lies in the fact that it was possible for plaintiff to so manipulate it as to dispense with defendant's services, without cause, before the expiration of the year, or compel him to accept less compensation than that fixed in the contract, or accept conditions more onerous than stipulated in the agreement, before being paid the contract salary."13 
The instant case together with the prior case of Blanchard $v$. Haber ${ }^{14}$ seems to constitute a departure in Louisiana law. The Blanchard case, rehed on by the court in the instant case, reached a similar result, not only upon the basis of lack of serious consideration, but principally upon the doctrine of potestative condition. ${ }^{16}$ The potestative condition, as defined in the code and interpreted by the Louisiana cases, simply means the type of condition which in common law makes a promise illusory. ${ }^{16}$ The term "serious consideration"17 has been held to mean something more valuable than a merely nominal consideration, as

14 (1928) $166 \mathrm{La} .1014,118$ So. 117 (Defendant, hired by plaintiff as dentist under a contract terminable on thirty days notice, promised not to compete in business district for ten years after employment).

${ }^{15}$ LA. Crv. Code (1889) art. 2024: "The potestative condition is that which makes the execution of the agreement depend on an event which it is in the power of one or the other of the contracting parties to bring about or to hinder...."

Ibid. art. 2034: "Every obligation is null, that has been contracted, on a potestative condition, on the part of bim who binds bimself."

Ibid. art. 2035: "The last preceding article is submitted to potestative conditions, which make the obligation depend solely on the exercise of the obligor's will; but if the condition be, that the obligor shall do or not do a certain act, although the doing or not doing of the act depends on the will of the obligor, yet the obligation .... is not void ..."

10 Campbell v. Lambert (1884) $36 \mathrm{La}$. Ann. 35 (Proinise to buy as unuch as buyer wished held not binding, following cominon law cases); Girault v. Feucht (1906) 117 La. 275, 41 So. 572 (Condition of buyer's obligation that he should not reject title to property lield not potestative, since buyer could not reject unless he found the title defective); Caddo Oil \& Mining Co. v. Producers' Oil Co. (1914) $134 \mathrm{La} .701,64$ So. 684 (Option to cancel lease held potestative); Nelson v. Barber (1918) $143 \mathrm{La} .783,79$ So. 403 (Grocer-baker requirement contract, with provision that grocer could sell other brands of bread for not less than four cents per loaf, lield not binding since no obligation on grocer to buy only from the bakerundoubtedly an erroneous decision on comnnon-law consideration rules and under the Louisiana code as well, since the grocer can buy froun another only if he resells at a certain price. See Corbin, The Effect of Options on Considerations (1925) 34 YaLe L. J. 571, Selected Readngs on Contracts (1931) 434); Kennon v. Brooks-Scanlon Co. (1920) 148 La. 120, 86 So. 675 (That plaintiff could refuse to receive mill-havings under contract if "unable for any reason" to do so, held not potestative since not dependent merely on plaimtiff's pleasure).

Cf. Professor Patterson's discussion of the potestative conditions, "Illusory" Promises and Promisor's Options (1921) 6 Iowa L. B. 129, 209, SeLECTEd REAdINGS ON CONTRACTS (1931) 401, 403 ff.

17 LA. Crv. Code (1889) art. 2464: "The price of the sale must be certain, that is to say, fixed and determined by the parties. It ouglit to consist of a sum of money, otherwise it would be considered as an exchange. It ought to be serious, that is to say, there should have been a serious and true agreement that it should be paid. It ought not to be out of all proportion with the value of the thing: for instance the sale of a plantation for a dollar could not be considered as a fair sale; it would be considered as a donation disguised ..."

Though specifically referring to the contract of sale alone, this article has been applied to all contracts as a "general primciple of the civil law and as old as the civil law itself." See cases cited in note 18, infra. 
the latter is known in the common law. ${ }^{18}$ But these two doctrines have been confused in some cases. ${ }^{19}$ Lack of a serious consideration would seem to create a potestative condition only when the consideration is in return for an option in regard to performance of a duty otherwise arising under the contract: for example, one dollar paid for an option given the lessee to cancel a lease containing a promise to drill wells. ${ }^{20}$ The instant case then is properly placed on the ground of lack of a serious consideration rather than on the ground of a potestative condition. ${ }^{21}$ The departure the case makes is in either treating the con-

18 Murphy v. Hussey (1906) 117 La. 390, 41 So. 692 (Option to buy contained in lease held not unenforceable for lack of consideration, citing cominon law cases); Murray v. Barnhart (1906) $117 \mathrm{La} .1023,42$ So. 498 (Nominal consideration of two dollars for right to cancel lease held not a serious consideration (art. 2464 applied) and hence lease invalid as on a potestative condition, the court distinguishing Houssiere Latreille Oil Co. v. Jennings-Heywood Oil Syndicate (1905) 115 La. 107, 38 So. 932, where the facts were similar except that one hundred dollars instead of two dollars was the consideration to be paid); Blackshear v. Hood (1908) 120 La. 966, 45 So. 957 (One dollar for privilege of cutting trees held insufficient); Succession of Witting (1908) $121 \mathrm{La} .501,46$ So. 606 (following Murphy v. Hussey, supra, the court saying that the option may not be treated as a separate agreement; compare the primcipal case, where the court apparently does separate the two agreements); Blanks v. Lephiew (1913) $132 \mathrm{La}$. 545,61 So. 615 (Option to cancel contract to buy lumber on paying five hundred dollars, after buying minimum of eight thousand dollars worth, upheld as a resolutory condition, under article 2045 of the Louisiana Civil Code); Caddo Oil \& Miming Co. v. Producers Oil Co., supra note 16 (One dollar not a serious consideration for option to cancel lease); Saunders v. Busch-Everett Co. (1916) 138 La. 1049, 71 So. 153 (Agreement to pay three per cent of market value of land yearly in return for option to drill for oil upheld); see Goodson v. Vivian Oil Co. (1912) 129 La. 955, 57 So. 281.

19 Blackshear v. Hood, supra note 18; Blanchard v. Haber, supra note 14. These cases seem unsound, under the code, in treating absence of serious consideration as necessarily creating a potestative condition.

20 The following cases properly treat the lack of a serious consideration as creating a potestative condition: Murray v. Barnhart; Goodson v. Vivian Oil Co., both supra note 18; Caddo Oil and Mining Co. v. Producers Oil Co., supra note 16.

21 It will be noticed that no mention is made of the much-debated doctrine of causa. That doctrine seems to have no application here. It is generally said to be broader than the doctrine of consideration, i.e., it will allow enforcement of promises in a greater number of situations. In the instant case the contrary seems to be true, of course. In all these cases cited in notes 18 to 20 , supra, a serious consideration in the sense of a true bargain equivalent seems to be required. $C f$. LA. Crv. Code (1889) art. 2464, supra note 17; ibid. art. 1768: "Commutative contracts are those in which what is done, given or promised by one party is considered as an equivalent to, or a consideration for, what is done, given or promised by the other."

In this type of contract, the statement made in 1 WIIIISTON, ConTrAcrs (2d ed. 1922) \$111, "As the Civil Law is in force in Louisiana, the requirement of consideration does not there obtain," seems open to qualification. It is of course trne that the doctrine of consideration is not adopted in its entirety; but consideration is required here.

On the nature and extent of the doctrine of causa, see: Poliock, PrInciples of Contract (9th ed. 1921) 182; Drake, Consideration versus Causa in RomanAmerican Law (1905) 4 Mrch. L. Rev. 19; Lorenzen, Cause and Consideration in the Law of Contracts (1919) 28 Yale L. J. 621, Selected Readings on Contracts 
tract as divisible so that there is no consideration supporting the covenant ${ }^{22}$ or holding that a promise to employ for two weeks is not a serious consideration. ${ }^{23}$

Would a common-law court be expected to follow the Louisiana court in the result of the instant case? ${ }^{24}$ Would it recognize the inequality of bargaining power? If so, what doctrines would be brought into play? The common law furnishes a number of possible objections to enforcement of the contract in question, some of which might be applied to equalize disparities due to the economic position of the parties. $^{25}$

(1931) 565; Pound, Consideration in Equity (1918) 13 ILI. L. Rev. 667, 683; Radin, Fundamental Concepts of the Roman Law, Part IV (1925) 13 CaLIr. I. REv. 119, 132; Walton, Cause and Consideration in Contracts (1925) 41 L. Q. REv. 306; Note (1929) 78 U. of PA. I. Rev. 261.

22 The court says: "The testimony in the present case shows that the salary paid to this defendant was only the usual salary paid to a laundry driver at that particular time, and so the salary itself does not in any way enter into the contract as a consideration for the restrictions placed upon the defendant. The sole consideration was the employment of this defendant by the plaintiff." 139 So. at 567 . Cf. Murphy v. Hussey; Succession of Witting, both supra note 18.

23 The court says: "This defendant gave up his right to earn $\$ 715.00$ in order that he might have the sum of $\$ 55.00$. The plaintiff gave up nothing, but merely gave to the defendant a contract of employment which could be terminated at the end of two weeks.

"This court has nothing to do with the adequacy of the consideration, but if wbat one gives up is out of proportion to the obligation which he assumes, then a court does have something to do with it. We think that the consideration which was given $\mathrm{m}$ this case; that is, the position for a period of two weeks, was altogether out of proportion to the obligation assumed by this defendant." 139 So. at 565 .

24 It may be significant that the circuit court of appeals in Cali v. National Linen Service Corp. (C. C. A. 5th, 1930) 38 F. (2d) 35, though deciding the case under Louisiana law, virtually refused to follow Blanchard v. Haber, supra note 14. The facts were similar to those in the instant case: A route foreman for a laundry service agreed not to compete for a year after termination of employinent. The company could discharge him on one week's notice. The court held tbe covenant enforceable, sayimg, "There is nothing in the case of Blanchard v. Haber, supra, compelling a reversal in this case. Doubtless, had the salary paid Haber been considered adequate and the restriction reasonable, the decision would have been different." $38 \mathrm{~F}$. (2d) at 37.

In the instant case the court points out that the Blanchard case did not rest on inadequacy of the salary as such; the salary was adequate as payment for services, but not also as consideration for the covenant. The court in the instant case says of the Cali case: "We think tbat Judge Foster's comment on the Blanchard case is entirely erroneous." 139 So. at 567.

The Cali case illustrates a common-law court's approach to the fact situation and to the civil law doctrimes involved. The Cali case has been followed in Wark v. Ervin Press Corp. (C. C. A. 7th, 1931) 48 F. (2d) 152 and distinguished in Super Maid Cook-Ware Corp. v. Hamil (C. C. A. 5th, 1930) 50 F. (2d) 830.

25 These possible objections will be taken up in the following order: 1 . Restraint of trade; 2. Lack of consideration; 3. Duress; 4. Equitable doctrines denying specific performance, 
Is the covenant in the instant case unenforceable as in restraint of trade? A partial restraint ancillary to a contract of employment will be upheld if it is reasonable, regard being paid to (1) the question of whether the promise is wider than is necessary for the protection of the employer, (2) the effect on the employee, and (3) the effect on the pubhic. ${ }^{26}$ Apparently most courts have no difficulty in holding the covenant valid. ${ }^{27} \mathrm{~A}$ vital point where the court in the instant case would disagree with the common law authorities is in regard to the employer's sole ownership of the good-will of the customers. The common law cases assume that such good-will belongs to the employer alone. ${ }^{28}$ This is further brought out in those cases which protect the employer even in

203 WILISTon, Contracts (2d. ed. 1922) \$1636. The test is "whether the restriction is such only as to afford a fair protection to the interests of the party in favor of whom it is given and not so large as to interfere with the interests of the public." Horner v. Graves (1831) 7 Bing. 735, 131 Eng. Rep. R. 284, quoted in Note (1920) 8 CAIIF. L. REv. 437, 439.

273 Wrutston, Contracts (2d. ed. 1922) $\$ \$ 1367,1643 ; 2$ Page, Contracts (2d. ed. 1920) \$780. Cases similar on their facts to the instant case are: Cali v. National Linen Service Corp., supra note 24; Sherman v. Pfefferkorn (1922) 241 Mass. 468, 135 N. E. 568 (Laundry solicitor employed at will enjoined from soliciting former customers for three years); American Ice Co. v. Lynch (1908) $74 \mathrm{~N}$. J. Eq. 298, 70 Atl. 138 (Ice-wagon driver enjoined from engaging in ice business for one year along route or within five blocks of it); Owl Laundry Co. v. Banks (1914) 83 N. J. Eq. 230, 89 AtI. 1055 (Laundry solicitor after fourteen months' employment enjoined from soliciting plaintiff's custoiners or engaging in the business in the county for two years); Hackett v. A. L. \& J. J. Reynolds Co. (1900) 30 Misc. Rep. 733, 62 N. Y. Supp. 1076 (Salesinan for wholesale grocery company denied recovery of deposit because of breach of covenant not to coinpete in New York or within ten miles of New York for six months); Mutual Milk \& Cream Co. v. Prigge (1906) 112 App. Div. 652, 98 N. .Y. Supp. 458 (Milk-wagon driver after employment lasting three months under a contract terminable on one week's notice enjoined against soliciting plaintiff's customers for three years); Mutual Milk \& Cream Co. v. Heldt (1907) 120 App. Div. 795, 105 N. Y. Supp. 661 (Injunction granted on saine facts as in preceding case, except that employment lasted seventeen inonths); Jennings v. Shepherd Laundries Co. (Tex. Civ. App. 1925) 276 S. W. 726 (Laundry agent under eimployment terminable on one weeks' notice enjoined from competing for two years).

28 See especially Super Maid Cook-Ware Corp. v. Hamil, supra note 24; Sherman v. Pfefferkorn, supra note 27 (An injunction was granted although the court says the defendant obtained many of the plaintiff's customers 'hecause of their friendly acquaintance with him") ; Stermberg v. O'Brien (1891) $48 \mathrm{~N}$. J. Eq. 370, 22 Atl. 348; Hackett v. A. L. \& J. J. Reynolds Co.; Mutual Milk \& Cream Co. v. Heldt, hoth supra note 27; Colonial Laundries Inc. v. Henry (1927) 48 R. I. 332, 138 Atl. 47; see PAGE, op. cit. supra note 27, $\$ 780$ (but Cf. 3 WIILISTON, Contracts (2d ed. 1922) \$1646); Notes (1928) 28 CoL. L. REv. 81, 85; (1929) 29 ibid. $347,351$. 
the absence of express covenant. ${ }^{29}$ But the Louisiana court in the instant case says: ${ }^{30}$

"The fundamental basis of plaintiff's contention rests upon its asserted ownership of, and property interest in, the patronage and good will of all customers along the route worked by defendant for it. It is this right which was sought to be protected and preserved by the contract. The evidence discloses, in fact it is not disputed, that the good will of a line of customers, built up on a given route, is brought into existence mainly by two concurring factors, viz: Satisfactory service by the employer and a solicitor who has tact and intelligence, and whose contact with his customers, from time to time, is such as to win and hold their confidence and friendly attitude. A discourteous and unaccomodating solicitor cannot succeed for himself or his employer. Therefore, the solicitor who has contributed so materially to the building up of a successful business on his route has a very valuable interest therein, concurrent with his employer, and could not be expected to divest himself of it without substantial consideration flowing to him. This right was vested in defendant when he signed the contract with plaintiff. The contract would strip him of it without anything of value in return, save retention in einployment under very precarious conditions. But for the contract this right would have been retained by him unimpaired, and he would have heen free to have exercised it for his own personal beneflt and advantage."31

29 The "trade secret" cases are to be distinguished. Solicitation of former customers has generally not been enjoined without express covenant, wrongful use of employer's property (lists of data belonging to employer, etc.), or other conduct amounting to unfair competition (such as failure to disclose the fact that a new employer is being served). See 2 Wutuston, Contracts (2d ed. 1922) \$1025; Notes (1913) 1 CaLrF. L. REv. 385; (1923) 11 ibid. 438, 440. But a number of cases extend the term, "trade secret," to cover names of customers, even though the customers are personally known to the employee who uses no list of any sort. See Empire Steam Laundry v. Lozier (1913) 165 Cal. 95, 130 Pac. 1180; New Method Laundry Co. v. McCann (1916) 174 Cal. 26, 161 Pac. 990, Ann. Cas. 1918C, 1022 ; Pasadena Ice Co. v. Reeder (1929) 206 Cal. 697, 275 Pac. 944; MacKechnie Bread Co. v. Huber (1923) 60 Cal. App. 539, 213 Pac. 285; Hackett v. A. L. \& J. J. Reynolds Co., supra note 27 (dictum, since express covenant); Colonial Laundries Inc. v. Henry, supra note 28; Notes (1913) 1 CAIIF. L. REv. 385; (1923) II ibid. 438 and cases therein cited; (1929) 29 Cor. L. REv. 347, 351.

It may be admitted that no distinction should he drawn on such a technicality as use of a written list or inemorized list, but the fundamental question still remains.

The California cases may he explaimed as a successful attempt to evade the provisions of sections 1673, 1674, and 1675 of the California Civil Code, which make all contracts in restraint of a lawful trade or business void, except those in connection with the sale of good-will of a business or in connection with retirement of a partner. The narrow territorial limitation of a city or county is imposed. These provisions have been criticised. See Harrison, The First Half-Century of the California Civil Code (1922) 10 CAIIF. L. REv. 185, 196; Note (1920) 8 ibid. 437. The California cases have been criticised in Notes (1913) I CaIIF. L. REv. 385; (1923) 11 ibid. 438 . But Cf. (1929) 18 ibid. 88.

30139 So. at 566.

31 It should be noted that the defendant knew his customers before being employed by plaintiff. Cf. Iron City Laundry Co. v. Leyton (1913) $55 \mathrm{~Pa}$. Super Ct. 93 (Employee was not enjoined from soliciting his employer's customers where 
It is submitted that the court displays the correct approach: that is, the employer should be protected in his legitimate interests without express covenant; if the covenant is broader than necessary for this purpose, it should be invalid to restrain the employee's action..$^{32}$ It may be argued that those customers successfully drawn away by the employee are those primarily interested in buying from him personally; hence the good will should be viewed as belonging to him. Customers primarily interested in patronizing the employer's business will not be drawn away, and the employer's property in the good-will will not be injured. In other words, the subsequent action of the custoniers deter-

the employee himself had furnished the customers to his employers at the beginning of the employment); New Method Laundry Co. v. McCann, supra note 29 (Defendant, independent owner of route before selling it to plaintiff and entering plaintiff's employ, was enjoined. See Note (1923) 11 CALIF. L. REv. 438, 441); Victor Chemical Works v. Iliff (1921) 299 IIl. 532, 551, 132 N. E. 806, 813 (Defendant himself discovered the process rehied on as a trade secret; injunction denied in spite of agreement that employer should own all such discoveries); Carpenter v. Southern Properties, Inc. (Tex. Civ. App. 1927) 299 S. W. 440 (Defendant ice retailer sold equipment to plaintiff and entered plaintiff's employ; injunction denied only because of plaintiff's breach of contract). But in the instant case, if defendant's former employer had owned the good-will, then it was undoubtedly transferred to plaintiff. At any rate the court speaks generally, and does not place its decision on the ground that the good will of the old customers alone belonged to defendant.

32 Note (1929) 29 Cor. L. REv. 347, 352: "It is believed that the delictual theory, besides being more in accord than the contract theory with the avowed economic postulates of the judiciary, will be a more helpful guide in the treating of cases . . The present analysis would make the disparity of bargaining power irrelevent since the prime consideration would be, not whether the employee has been sufficiently recompensed so that he may no longer enjoy benefits as a competitor, but whether by his unfair tactics he is apt to injure a legitimate interest of his former einployer. If we are to give rigorous logical effect the policy arguments that the courts profess to espouse we must reach the conclusion that in no case where a restraint cannot be achieved without a contract should we permit it to be achieved with a contract."

Note (1923) 11 CALIE. I. REv. 438, 443: "In cases where injunctions are to be issued, or where they have been issued and questions of violation arise, the courts can only determine each case on the particular facts involved, bearing in mind the right of the employee to pursue his occupation, the right of the public to deal with any company that they choose, and the employer's right to protection from excessive mjury at the hands of his former einployee. It seems that New Method Laundry Co. v. McCann and the principal case (Mackechnie Bread Co. v. Huber, supra note 30 ) have overemphasized the necessity of protecting the employer in California. Unfortunately, the distinction between those cases where the employee unfairly injures his former employer, and those cases where an innocent employee legitimately seeks to better his status has not been preserved. To extend equitable protection to an extreme is to prejudice both the rights of the employee and of the customer. It is to be hoped that equitable protection will be limited to those cases where the injury to the employer manifestly outweighs the consideration due the employee and the public."

See Gilbert v. Wilner (1918) 102 Misc. Rep. 388, 168 N. Y. Supp. 1043; Note (1928) 28 Cor. L. REv. $81,85$. 
mines the extent of the respective interests of the employer and the employee. ${ }^{33}$ It would seem then that the employee in the instant case should not be restrained either with or without an express covenant. But it is clear that many courts would have reached a contrary result to that in the instant case, in so far as the validity of the covenant is concerned..$^{34}$

The question in the instant case is not primarily whether the contract is in restraint of trade, however. The Louisiana courts have upheld such covenants in connection with the sale of a business. ${ }^{35}$ It does not appear that the court in the instant case would refuse to enforce the covenant if the defendant had been adequately recompensed for giving it. There would then be in effect a relinquishment of the defendant's rights in the good-will.$^{36}$ Inequality of bargaining power then should not be a factor in the decision on the question of reasonable restraint.

33 In Sachter's Ice Cream Co. v. Sunshime Ice Cream Co. (1921) 116 Misc. Rep. 428,190 N. Y. Supp. 391, defendant was a driver and solicitor for an icecream company. Plaintiff asked an injunction against serving plaintiff's customers (no express covenant). The court said: "To agree with the plaintiff's contention would be an end. of ambition in the salesman and of incentive to the plaintiff to maintain the grade and quality of his goods, and would put an end to that fair competition based upon such quality and endeavor which the bealth of the trade required ...

". . . upon these authorities and upon general primciples of law and cquity and sound economics, the motion for a temporary mjunction is denied." 116 Misc. Rep. at 428,190 N. Y. Supp. at 392.

But see Colonial Laundries Inc. v. Henry, supra note 28. The court says: "Knowledge of the route enabled respondents to compete not only by the offer of equal or superior services and on equal terms, but to take advantage of the money and labor spent by complainant to group selected people on a particular route. ... In cases involving milk, ice, laundry, and tea routes, a list of customers cannot be thus obtained; a definite, selected group bas been gathered together by the employer, not of persons who may deal with him, but who, if not specially solicited otherwise, almost certainly will do so ... The given customers pay little attention to whose services they receive. The quality of the service rendered is so similar that the customer invites the person rendering the service to call at definite periods and to keep on rendering such service until further notice ..." 48 R. I. at 337, 138 Atl. at 49. See Super Maid Cook-Ware Corp. v. Hainil, sulpra note 24.

34 See further on covenants not to compete: Kales, Contracts AND Combinstions in Restranti of Trade (1918) 4 ff; (1926) 40 Harv. L. Rev. 319; (1926) 40 ibid. 326; (1932) 45 ibid. 750; (1932) 45 ibid. 751.

35 Goldman v. Goldunan (1899) 51 La. Ann. 761, 25 So. 555 ; Eugene Dietzgen Co. v. Kokosky (1904) 113 La. 449, 37 So. 24; Moorman \& Givens v. Parkerson (1911) 127 La. 835, 54 So. 47; Mouton v. Marshall (1920) 147 La. 458, 85 So. 204 ; May v. Johnson (1930) 13 La. App. 521, 128 So. 540; Ullman \& Co. v. Levy (1931) 172 La. 79, 133 So. 369; see Vonderbank v. Schmidt (1892) 44 La. Ann. 264, 10 So. 616, 15 L. R. A. 462; Webb Press Co. Ltd. v. Bierce (1906) 116 La. 905, 41 So. 203.

36 There was such an express relinquishment in the contract, but this was of course held to be without serious consideration.

See the court's comment as to the covenant in the Blanchard case. The supreine court in the Blanchard case "did intimate that the restriction both as to time and territory was unreasonable." 139 So. at 567. 
Would the contract in the instant case be held void for lack of consideration in a common-law court? The provision for two weeks' notice prevents the promise to employ from being illusory. ${ }^{37}$ Even where the employment is at will most courts uphold a covenant like that in the instant case where performance under the contract has been rendered for a substantial period. ${ }^{38}$ The promise to employ is sufficient consideration for both return promises made by the employee-to render services and not to compete after the termination of the employmentsince all promises are made simultaneously as part of one contract. ${ }^{39}$

In the instant case the employer threatened to discharge the employee if the latter failed to sign the restrictive covenant, well knowing that the employee had no other means of making his hiving than that offered by his present employment. Is such conduct "duress" under the common law? Economic duress, i.e., lack of choice of action by reason of financial necessity and in a broader sense by reason of servient economic position generally has not been recognized expressly by the courts. The growth of the law has been from a narrow view of what constitutes duress to a broad one, ${ }^{40}$ but that growth is slow. ${ }^{41}$ In general, financial necessity may be taken advantage of so long as the necessity is not caused by wrongful act of the enforcing party. ${ }^{42}$ Even

372 PAGE, op. cit. supra note 27, \$573; Corbin, The Effect of Options on Consideration (1925) 34 Yale L. J. 571, Selected ReAdings on Contracts (1931) 434, 450; Whittier, The Restatement of Contracts and Consideration (1930) 18 CaIIf. L. Rev. 611, 626; Note (1929) 29 Cox. L. REv. 347, 349; cases cited in note 27, supra.

38 See an excellent discussion in Note (1929) 29 Cor. L. REv. 347. For example see Sherman v. Pfefferkorn, supra note 27; Freudenthal v. Espey (1909) 45 Colo 488, 102 Pac. 280. But cf. Super Maid Cook-Ware Corp. v. Hamil, supra note 24; Gilbert v. Wilmer, supra note 32.

391 Wristston, Contracts (2d ed. 1922) §141; Restateanent of the LaW of Contracts (Am. L. Inst. 1928) §83.

403 WIILISTON, Contracts (2d ed. 1922) \$1603: “. . . there is no doubt that the modern tendency of courts of law is to regard any transaction as voidable which the party seeking to avoid was not bound to enter into and which was coerced by fear of a wrongful act by the other party to the transaction." Cf. Albertsworth, Is There a Legal Cycle? (1923) 11 CaIIF. L. Rev. 381, 392 (Similar enlarginent in the scope of duress traced in the civil law and the common law.)

41 Llewellyn, op. cit. supra note 3, at 728, note 49: "Agreeinent' does not even today carry any necessary connotation of real willingness. Acquiescence in the lesser evil is all that need be understood. The problem of 'reahty of consent' is essentially one of determining what types of pressure or other stimuli are sufficiently out of line with our general presuppositions of dealing to open the expression of agreement to attack. 'Economic duress' is still the order of the day save for particular exceptions (usury equity of redemption, duress of goods.)"

422 PAGE, op. cit. supra note 27, \$492; 3 WIIIISTON, ConTrACTs (2d ed. 1922) $\$ 1608$; Note (1919) 7 CarIF. L. REv. 188. Professor Williston believes that the contract might be unenforceable if one party knows and takes advantage of the other party's unfavorable position. 3 WIIITSToN, loc. cit. supra (no citations). 
threatening to break a contract will not constitute duress, ${ }^{43}$ and in the instant case the enployer's threat did not necessarily involve breach of the contract, which was terminable on two weeks' notice. In general, threatening to do what one has a right to do does not constitute duress. ${ }^{44} \mathrm{~A}$ relation giving dominance to one party may be an element in constituting duress, ${ }^{45}$ but the ordinary relation of employer and employee has not been held to be included within that category..$^{46}$ It may well be that in time the conception of duress will be enlarged to cover this situation, but today the contract in the instant case would not be held invalid in a common-law court.

Would any equitable doctrine deny specific performance in the instant case?47 The following circumstances, or combinations of them, have been considered grounds for denying equitable relief: inadequacy of consideration, harshness, hardship, unfairness, relationship giving one party doninance over the other. Inadequacy standing by itself must be extreme, ${ }^{48}$ but when coupled with other factors may justify relief. ${ }^{40}$ Hardslip, harshness, and unfairness are lardly subject to definition ${ }^{60}$

43 Notes (1919) 7 CaIIF. L. REv. 188; (1921) 9 ibid. 492; (1927) 40 HaRv. L. REv. 1000. "But our courts have looked with wholesome disfavor on suggestions that fear of discharge may constitute an element of duress." Ibid. at 1002, with citations. Cf. CAC. CIv. CoDE $\$ \S 1569,1570$. Apparently such a threat is recognized as duress in the civil law. See Note (1921) 9 CALIF. L. REv. 492, 494.

That a threat to break a contract should constitute duress appears also in connection with another prohlem-whether there is consideration for a recission and substitution of a new contract with increased performance provided for on one side only. When such an arrangement is fairly made, there seems little doubt that it should stand. But many if not most courts refuse to uphold the new agreement. If the new contract is induced by threats of repudiation without just cause, it should be voidable for duress. But the concept of duress will not at present cover this situation. See Note (1921) 9 CALIF. L. REv. 492. Some recent cases uphold the new contract, however. See (1928) 23 IIr. L. REv. 87; (1921) 20 MTCF. L. REv. 104; (1928) 26 ibid. 447; (1928) 37 YaLE L. J. 520. But see 1 Wuliston, Contracts (2d ed. 1922) §§ 130, 130a.

443 Wintiston, Contracts (2d ed. 1922) \$1060; cf. La. Civ. Code (1889) art. 1856. (A threat of doing what one has a right to do will not invahidate a contract); Drake, op cit. supra note 21 , at 19,30 .

453 WIILIston, Contracts (2d ed. 1922) \$1627.

$40 \mathrm{Ibid}$. This question is also treated as an equitable doctrime preventing specific performance. See note 52 , infra.

${ }^{47}$ The relief, injunctive $i \mathrm{~m}$ form, is really specific performance of the covenant not to compete. See Fry, Specific Perforacance (6th ed. 1921) \$145; Pomeroy, Specific Perforacance (3d ed. 1926) \$25.

48 Pomerox, op. cit. supra note $47, \$ 194$ ff; 3 Wurtiston, Contracts (2d ed. 1922) §§ 1428, 1636; (1922) 22 Cos. L. REv. 675 (The disproportion unust be so enormous that no reasonable man in his full senses would have assented). But see Note (1927) 27 ibid. 178.

40 Pomeroy, op. cit. supra note 47, \$196; 3 Williston, Contracts (2d ed. 1922) $\$ 1428$.

$50 \mathrm{FRY}$, op. cit. supra note 47, §399 ff; POMERox, op. cit. supra note 47, §§ 175191; Notes (1909) 9 Cor. L. Rev. 68; (1927) 40 Harv. L. Rev. 1000.

"A contract by which the defendant contracts to part with his future means of hivelihood is looked upon with disfavor and will not be specifically enforced." 3 Wiltiston, Contracts (2d ed. 1922) §1425. 
but depend on particular facts, and of course the remedy is withm the discretion of the court. ${ }^{51}$ The employer-employee relationship as such has not been considered one giving the employer such dominance that equity will consider the factor. ${ }^{52}$ In the principle case the consideration is inadequate, ${ }^{53}$ but probably not so inadequate as to justify rehef on that ground alone.54 The harshness and hardship involved in enforcing the covenant seem clear-the defendant's earning power is substantially decreased for the period of the covenant. ${ }^{55} \mathrm{~A}$ few courts have denied injunctive rehef in cases similar to the instant one..$^{56}$

51 See authorities cited in notes 47-50, supra.

52 3 WILLISTON, Contracts (2d ed. 1922) \$1627; Note (1927) 40 Harv. L. REv. 1000. "The relation of employee to employer is still one which originates in free contract of the parties; and the pressure is ordinarily not strong enough to assimilate this relationship to those extraordmary situations where equity will recognize the effect of external economic stress." Ibid. at 1002.

Cf. Pound, Interpretations of Legai History (1930) 123: "Equity has been the de facto inequality between fiduciary and beneficiary and between lender and borrower because of the advantageous position of the former in each case. The common-law courts had seen the de facto inequality between public utility and patron. Courts and legislatures have seen the de facto imequality between insurance company and insured. In such cases and many more like them the law had regulated the contracts which the parties might make in these relations in order to insure that no advantage slould be taken of the actual inequality and that the contracts made should be fair. But the legislature could not recognize the de facto advantage of employer over employee where the employer was a mining corporation because that advantage had not yet taken form in a legal conception. It was but de facto. To recognize it was 'arbitrary.' Legal conceptions were like Lewis Carroll's watch. Facts had no more effect upon the one than time upon the other."

53 The court says: "This defendant gave up lis right to earn $\$ 715.00 \mathrm{~m}$ order that he might have the sum of $\$ 55.00$." 139 So. at 565 . Of course the defendant really expected in return a tenure as employee which would enable him to earn much more than two weeks' salary; but the plaintiff was bound to pay him no more. In fact one defendant was employed for eleven months after signing the contract; the other for six.

54 See authorities cited in notes 48, 49, supra; Freudenthal v. Espey, supra note 38.

55 The court says: "The remedy sought by plaintiff is a larsh one, and a justifiably unpopular one with employees generally, and should not be applied by the courts oppressively, nor in any case, unless the restriction sought to be imposed is clearly reasonable and necessary for the protection of plaintiff's rights." 139 So. at 566 .

56 Victor Chemical Works v. Пliff, sulpra note 31 , at 550,132 N. E. at 813 : "He got no money or property for signing the contract, by way of increase of wages or otherwise. He got no extension of time of his contract of employment. The contract does not bind complainant to keep him in its employment for any length of time, but reserves the right to terminate it at any time on reasonable notice. It would be very imequitable to enforce this contract even if the process aforesaid were secret;" Fries v. Parr (1912) 139 N. Y. Supp. 220 (Defendant sold his business to plaintiff and promised not to engage in the saine business for ten years, in return for plaintiff's promise to einploy defendant for one year; consideration held inadequate and injunction refused, though other grounds were plaintiff's breach of contract and laches); Gilbert v. Wilmer, supra note 32. Contra: Cases cited in notes 27,29 , supra passim. 
Probably the strongest ground for denying relief has been a sympathy for the underdog, the servient party, even though this ground is often not expressly recognized. ${ }^{57} \mathrm{It}$ would seem preferable to recognize this factor expressly, to bring it out into the light, where it can be made a matter of investigation and not merely of uninformed sympathy. Courts of equity are in an especially favorable position to do justice in this type of case by extending the scope of these equitable doctrines. ${ }^{68}$ Again, the comon-law method of pricking out new extensions and limitations by case-to-case procedure is an excellent and effective one. But both the true springs of action and the end of that action must be in view. "To believe that the common-law is not adequate for every need is to fail to grasp the history of the common law and to understand what the common law is."

Frederick E. Hines.

SCHOOL, OF LAW, UNIVERSITY OF UTAH.

57 For example see Gilbert v. Wilmer, supra note 32, at 339, 168 N. Y. Supp. at 1044: "The plaintiffs therefore seek the aid of the court of equity in their competition with this laborer, who is seeking to support himself and those dependent upon him by the labor of his own hands. The defendant must be a very energetic and successful window washer to imperil a 'large and extensive business' in five days hy his unaided efforts."

Cf. Notes (1929) 29 CoI. L. Rev. 347, 348, 352; (1927) 40 HARv. L. REv. 1000.

68 We may agree with the writer in Note (1927) 27 Cor. L. REv. 432, 435, when he says: "To permit the retention of an advantage gained by greater foresight or higher husiness acumen is no more than to assist the constant elimination of the unfit which is one purpose of our entire social organization. But to apply the same considerations to a formally identical agreement in which the inaccuracy of the valuation is due not to the superior intelligence but to the superior bargaining power of the dommant party would he too great a sacrifice to simplicity of the law.

"It is not suggested that the courts enter upon the task of revalueing the consideration or weighing the hargaining powers of the parties to every agreement. It is submitted that they should be less willing to close their eyes to obvious inadequacies and imequalities for the sake of deciding in accordance, with a convenient principle of delusive simplicity."

50 Llewellyn, $o p$. cit. supra note 3 , at 732, n. 62: "I should have no criticism of this case-to-case procedure if it were directed at what seems to me to be the true issue: finding and marking out type situations in which hinits of permissible bargaining require to he laid down; or finding and marking out types of parties who require to be limited in their bargaining with each other-and then spotting what the needed limitations are. With such an objective the case-to-case procedure can work to beautiful results, avoiding premature definition, accumulating experience, yet meeting current needs. But in the newer lop-sided contracts the courts make little headway in the process because they do not see the goal."

But Cf. Note (1931) 31 Cox. L. Rev. 830, 841.

60 Adler, op. cit. supra note 1, at 272. 